\title{
Mitigating circumstances
}

\section{There are many barriers that must be overcome if South Africa is to control its greenhouse-gas emissions.}

After his party's victory in South Africa's 2009 elections, one of President Jacob Zuma's earliest successes was achieving his country's entry into BRIC, the association of emerging economies originally constituted by Brazil, Russia, India and China. Now known accordingly as BRICS, the member nations are widely known for their economic growth, especially since the slump of the 1990s. South Africa's inclusion makes the group even more of a force to be reckoned with in international trade, development and climate change negotiations. There is even talk that BRICS could be pivotal in setting up a climate agency, perhaps spearheaded by China (The Guardian, 28 January 2013; http://go.nature.com/wqdizO). The creation of an agency like this would be welcomed by many; among other things it could develop suitable adaptation and mitigation policies for developing nations, facilitate technology transfer and foster climate surveillance and monitoring. The member states of BRICS certainly have the means, know-how and motivation to plough ahead with such an initiative.

South Africa itself certainly has good reason to act on climate - not just in terms of reputation, but also as part of a broader aim of ensuring a greener, cleaner future. The country is heavily dependent on coalfired power plants for electricity generation. These facilities - some of them among the dirtiest in the world - are responsible for a large proportion of national carbon dioxide emissions, and the country is by far the largest emitter in Africa. One would have thought that hosting the 2011 Conference of the Parties climate negotiations in Durban would have provided a powerful impetus to take decisive action. But this does not seem to have been the case; a previously announced carbon tax, for example, has been postponed to 2015 .

The reasons for the apparent inertia are discussed by Anna Petherick (page 308). Among them are institutional malaise and mutual distrust between large companies and the government. Perhaps more understandable are the legitimate concerns that carbon taxes might actually increase social inequality.

What of the future? As Petherick suggests, mitigation is the name of the game when it comes to South Africa's priorities in response to climate change. Options for reducing dependency on coal include building new nuclear power plants in addition to the two operational reactors at Koeberg in the Western Cape, or exploiting vast shale-gas reserves below the ecologically sensitive Karoo region by means of fracking. Neither of these options is particularly palatable, but may well come to pass. The development of clean, renewable energy sources and increased energy efficiency will play their part, but for the foreseeable future coal remains king. No doubt cognizant of this, the government established the South African Centre for Carbon Capture and Storage (www.sacccs.org.za) in 2009 to investigate the feasibility of CCS in South Africa. It could one day become a necessity.

\section{Climate consensus}

\section{People's acceptance of global warming can be influenced by many filters.}

Collectively our individual lifestyle choices and support for or resistance to government policies make us - as members of society - key players in the climate change, and indeed any, debate. In our social lives, we are motivated by a combination of values, norms, beliefs and interpretations of the world, many of which are now challenged by global warming. Therefore, it is not surprising to see a growth of work exploring individual perceptions of, and trends in public opinion about, anthropogenic climate change.

Psychologists, sociologists and political scientists have focused on different factors shaping public views of global warming. However, they all discuss - albeit from different angles - the role of scientific information, and in particular perceptions about the degree of scientific consensus on climate change. As shown in the Article by Lewandowsky and colleagues (page 399) that also appears in our web focus 'Public and experts' views about climate change', individuals are more likely to attribute long-term climatic trends to human causes once informed of scientific consensus on anthropogenic global warming.

The good news for those concerned with climate communication is that there is a great deal of scientific agreement on the issue. The bad news is that climate is inherently uncertain - mainly because of the internal variability of the climate system. As a result, climate models can deliver a range of results, and communicating to the general public that there is scientific consensus - despite the uncertainties - gets complicated. Climate change experts have to work in the face of these inherent uncertainties. They can certainly improve models, but they may have to work also on the basis of their judgement. Expert judgement elicitation a tool used in medicine, engineering and natural sciences to determine the degree of scientific consensus and explore collective views on uncertainties - is gradually making its way into the climate science community. The study by Bamber and Aspinall on page 424 (see also the News and Views on page 311) demonstrates that it can help to quantify uncertainties around the contribution of ice sheets to future sealevel rise. Hopefully, this tool will also help communicators.

Communication of climate consensus among scientists is not enough to explain trends in public opinions though. Evidence indicates (Nature Clim. Change $2,236-237 ; 2012$ ) that in the US, for example, when political groups show consensus on anthropogenic global warming, the public follows and the societal level of concern rises. It follows that mass communication of scientific information, and even scientific agreement on climate change, may have limited impact if political elites continue to disagree on the issue. And influencing the public in polarized contexts is surely a challenging task. 